\title{
A Study on Agro-Forestry System and Forest-People Relationship in the Villages of Tehri Garhwal, Uttarakhand
}

\author{
Kalpana Bahuguna $^{1}$ and Sonali Maithili ${ }^{2}$ \\ ${ }^{1}$ College of Forestry VCSG Uttarakhand University of Horticulture and Forestry, Ranichauri, \\ Tehri Garhwal-249199, Uttarakhand, India \\ ${ }^{2}$ Indian Institute of Technology (ISM), Dhanbad, Jharkhand-826004, India \\ *Corresponding author
}

Keywords

Agro-forestry, Tehri

Garhwal, Fodder,

Livelihood

Article Info

Accepted:

07 September 2020

Available Online:

10 October 2020

\section{A B S T R A C T}

Agro-forestry is the most common land use practice in Garhwal Himalayan region. The people, agriculture and forests are inseparable in the villages which are at fringe or inside the forest area especially the hilly areas of Garhwal Himalaya. Garhwal Himalayan region of India is peculiar because the forest is a part of their life in the form of fodder, fuelwood, wild edibles and other livelihood necessities. The villagers not only utilize the forest products but also treat the forests as their precious treasure and protect them from many illegal and destructive activities. As in case of villages of Tehri Garhwal, the fodder and fuelwood is the main requirement from the forest. The agroforestry system and village policies are different in different villages with least to maximum involvement of forest department and personnel in various forestry activities. The ownership of the forests varies from the government owned forest to the forest owned by village panchayats. In either case, the overexploitation of nearby forests was mostly found absent from the villages of Tehri Garhwal, Uttarakhand.

\section{Introduction}

Agroforestry is a land use system in which, the woody perennials are integrated with the crops/animals components on a same land management unit (Nair, 1979). In the Garhwal Himalayan regions, it is very common for people to practice the agroforestry system as the farmers cultivate various crops, trees and rear livestock on the same unit of land. Most of the villages of Tehri Garhwal are at the fringe of the forest areas so the presence of trees on farmers field and dependence of villagers on these trees has became a common practice. Most of the trees present on farmers field and nearby areas are 
of multipurpose in nature and provide fodder, fuel wood, fruits, fibers etc. for the fulfillment of livelihood as well as daily need purpose of village communities.

District Tehri Garhwal has the $56.70 \%$ of its geographical area under forests (Forest Survey of India, 2017) with the highest geographical area $(2.13 \%)$ under agro-forestry system in Uttarakhand (Mahato et al., 2016). The tree-crop-people relationship in Garhwal is a permanent feature of this landscape. Trees are the most important component of the land use because it maintains the fertility and integrity of soil for crops to sustain and it also provide fodder, fuelwood, fruits etc during the time of extreme winters and scarcity. Although the farmers have very few choices for selecting the trees for agroforestry but still they have adapted to utilize trees already present on their fames to the maximum extent. The study for forest-crop-people relationship in Garhwal Himalaya is important because there is a need of sustainable indigenous agroforestry system to overcome the problem of shrinking agroforestry areas in hilly regions which are mainly due to the scarcity of water and climate change.

\section{Study area}

Tehri Garhwal district lies in the hills of Garhwal Himalaya where agriculture is a main occupation with 61,569 ha. land under agriculture out of which, only $7.4 \%$ land is under irrigated conditions (Srivastava, 2007).

In the present study, two revenue villages from district Tehri Garhwal were selected. Revenue village Khandkari consists of two villages- Village Khandkari and Village Mathesari with total 112.69 ha. Area, 69 households and a population of 350 people.

Revenue village Khimara consists of five villages naming Village Khimara, Chawadant,
Bhaintogi Sera, Tudi and Shoklpur. Revenue village Khimara has 67.45 ha. area and 100 households with the total population of 421 .

\section{Materials and Methods}

The trees and crops present on the revenue village Khandkari and revenue village Khimara were assessed. The questionnaire survey along with personal interview was carried out in the study areas with the series of questions related to the existing agriculture and agro-forestry practices, villagers dependency on forests, role of forest department and the local communities/village panchayats/van samiti and how all this effects the daily life as well as the livelihood of farmers and villagers. The responses from people were assessed to generate an idea of forest-crop-people relationship in the revenue village Khandkari and the revenue village Khimara of Tehri Garhwal, Uttarakhand.

\section{Results and Discussion}

\section{Agriculture and Agro-forestry}

The agriculture system and crop pattern in the both of the revenue villages were similar. Kharif and Rabi seasons were the most common crop seasons practiced in the study area with Kharf season prevailing in OctoberMarch and Rabi season from April to September. During Rabi season, "Baranaja" crop which locally means 12 crops, were cultivated among which five cereal crops (Oryza sativa -Rice; Amaranthus cruentusChaulai; Echinochloa frumentoaceaJhangora; Eleusine coracana- Maduwa and Zea mays- Maize) and three pulses (Macrotyloma uniflorum- Gahath; Phaseolus vulgaris- Chemi and Cajanus cajan- Tur) are the most important crops. Cucurbita maxima (Pumpkin) and Lagenaria siceraria (Bottle gourd) are the two most grown vegetables in this area. During Kharif season, Triticum aestivum (Wheat) is the major cereal crop. 
Agri-silviculture systm and the agri-hortisilviculture system were the most common agro-forestry system as well as the land use system being followed in the study villages. Major agro-forestry trees which are preferred by farmers on their field are- Grevia optiva (Bheemal), Celtris australis (Khareek), Melia azedarach (Dainkan) and Toona serrata (Toon). These species are planted on agricultural fields as well as the nearby areas of villages because during the extreme winters and peak summers, when there is fodder scarcity, these trees are lopped for the fodder. Other important tree species present in the nearby areas are- Bauhinia purpurea (Guriyaal), Bauhinia variegate (Kachanaar), Betula alnoides (Himalayan Birch), Bombax ceiba (Semal), Desmodium elegans (Chamlai), Cassia fistula (Amaltas), Cedrus deodara (Deodar), Emblica officinalis (Amla), Ficus palamata (Bedu), Ficus roxburghii (Timla), Melia azedarach (Dainkan), Morus alba (Mulberry), Myrica esculenta (Kafal), Pyrus pashia (Mohl), Quercus leucotrichophora (Ban oak), Rododendron arboretum (Buransh), Alnus nepalansis (Utees). These tree species are used primarily used for the extraction of fodder and fuelwood. Among all the tree species, Grevia optiva was the most important tree species for the locals as it is the main source for nutritious cattle fodder, fuelwood, fiber and small timber. As the forest nearby is dominated by Pinus roxburghii (Chir pine), the occurrence of fire in summer season is common in these forests. Chir pine also creates the water scarcity in nearby area as the ground water table reduces. The fruit tree species like Malus domestica (Apple), Prunus armeniaca (Chulu), Citrus sinensis (Malta), Juglans regia (Walnut) were commonly present in the agroforestry systems.

\section{Forest-people relationship}

The responses of questionnaire survey and personal interview conducted in the revenue village Khandkari and revenue village Khimara were assessed to generate an idea of forest-crop-people relationship in the study villages of Tehri Garhwal, Uttarakhand.

In the revenue village Khandkari, the forests near the village community or Gram Sabha were owned by Van Panchayat Samiti (Forest Panchayat Community) and a substantial area of nearby forest was owned by village community. Forest department plays comparatively small role in the protection and regeneration activities of forest. In the village, a forest community (Van Samiti) was formed by villagers which is headed by the Pradhan of the village. The Van Samiti plays an important role in people and forest relationship as it monitors all the forest area which is owned by forest community and in case of any illegal logging or felling or any other illegal activity in forest which is done without the permission of Van Samiti or the Forest Department, it communicates this information/complain to the Forest department and if found guilty, the proper punishment is given. As the main livelihood of villagers is agriculture and livestock specially cows, buffalo and goat so the villagers are highly depend on forest for fodder. Earlier the fuelwood requirement was also fulfilled by forest of village community but due to the increasing use of gas cylinders and LPG for cooking purpose, the demand of wood for fuel purpose is highly reduced. In earlier times, the consumption of fuelwood was more and there were no limit of the small wood which can be extracted from forest by one person at a time because the population of are as compared to nearby forest area was very low. As the role of Forest department in village is concerned, forest department always controls the fire with the help of local people and the members of forest community (Van Samity) of village but the forest department never shown any concern towards plantation and closing the regeneration area for protection purpose. 
The Revenue village Khimara was different from revenue village Khandkari because the most of the forest area around villages are under forest department and a very negligible area of forest was under village panchayat. The forest department carries out plantation activities frequently and proper closing cycle is followed for protection of regeneration. During the closure, only limited amount of extraction of fodder is allowed and the grazing in regeneration is prohibited. Grazing of cattles and extraction of wood and small timber is allowed and there is no limit on quantity of small wood and fodder a person can extract at one time. Because it never needed due to decreasing utilization of fuelwood as the use of LPG gas is easy.

It is concluded, in the district Tehri Garhwal, the tree-crop relationship is more like a necessity than the choice for people. The tree species like Grewia optiva and Quercus leucotrichophora play a very important role in livelihood of village/fringe people as these trees provide fodder during the lean period especially in hilly regions. Although the agriculture in these areas do suffer because of fragmented/marginal land area, low water table and low soil fertility but on the other hand, the woody component plays a major role in balancing the water cycle and nutrient cycle along with fulfilling the fodder, fuelwood and other minor forest product requirements of the villagers. As compared to the role of forest department, the role of village panchayat is more crucial in monitoring and controlling the regeneration of forest tree species and the utilization of minor forest products by the villagers. Generally the people from local and village areas of Garhwal regions protect the nearby forests. The feel of belongingness towards forest is enough for conservation and protection of forest. Apart from this, the villagers themselves have awareness against the misuse of forest resources and overexploitation.

\section{References}

Forest Survey of India, Dehradun (2017). India State of Forest Report.

Mahato S, Dasgupta S, Todaria NP, Singh V. (2016). Agroforestry mapping and characterization in four districts of Garhwal Himalaya. Energy, Ecology and Environment. 1, 86-97

Nair PKR. (1979). Agroforestry Research: A retrospective and prospective appraisal Proc. Int. Conf. International Cooperation in Agroforestry. ICRAF Nairobi. pp. 275-296.

Srivastava AK. (2007): Enhancement of livelihood security through sustainable farming systems and related farm enterprises in North-West Himalaya. [Project Report.] Almora, Vivekananda Parvatiya Krishi Anusandhan Sansthan: 16.

\section{How to cite this article:}

Kalpana Bahuguna and Sonali Maithili. 2020. A Study on Agro-Forestry System and ForestPeople Relationship in the Villages of Tehri Garhwal, Uttarakhand. Int.J.Curr.Microbiol.App.Sci. 9(10): 642-645. doi: https://doi.org/10.20546/ijcmas.2020.910.076 